Journal of Awareness

Cilt / Volume 4, Sayı / Issue 4, 2019, pp. 455-466

E - ISSN: 2149-6544

URL: https://www.ratingacademy.com.tr/ojs/index.php/joa

DOI: https://doi.org/10.26809/joa.4.035

Araştırma Makalesi / Research Article

\title{
INCLUSIVE EDUCATION IN MULTICULTURAL ENVIRONMENTS IN EUROPE AND THE BALKANS
}

\author{
Vedat BAJRAMI * \\ * Ph.D., Faculty of Education, University \& "Ukshin Hoti" in Prizren, KOSOVO \\ e-mail:vedat.bajrami@uni-prizren.com
}

Geliş Tarihi: 30 Eylül 2019; Kabul Tarihi: 20 Ekim 2019

Received: 30 September 2019; Accepted: 20 October 2019

\begin{abstract}
The paper is a result of a research of education systems, systems of support, legislation and evaluation of positive practice in the nine countries of the European Union and three countries in the Balkans: Montenegro, Macedonia and Kosovo. The condition for the research countries to be included in the sample is based on the population number not being larger than 8 million. Because of the relevance of the comparative analysis, two older state members of the European Union were chosen (Austria, the Flemish and the French region of Belgium), fourrecent EU member states (Estonia, Cyprus, Latvia and Slovenia), three Scandinavian countries (Iceland, Finland and Norway) and three countries in the Balkans: Kosovo, Macedonia and Montenegro. The aim of the research, besides defining the currentand basic definitions in exploring the description of the education systems of individual countries, is to present practices of inclusion of children with disabilities and multi-lingual children to carry out the processes of inclusion. The aim was achieved through the tasks of including children with SEN and multi-lingual children in individual countries in Europe and in the Balkans, through the analysis of the legal framework andthe organization of the education system in the individual countries enabling inclusive processes, by determining differences in relation to the systems of individual countries which are inclined to mainstream or special education, by identifying the support the particular groups of learners: children with SEN and multi-lingual children receive within the school system, by bringing out examples of good practices.
\end{abstract}

Key words: Education system, children with special educational needs, children with disabilities, inclusive education, European Union. 


\section{INTRODUCTION}

The European Agency for Special Needs and Inclusive Education (further the Agency), emphasizes that everything that is good for the children with special needs is actually good for all children (Meijer, 2003, p. 4). Throughout Europe there is a tendency of development of new forms of inclusion of children with SEN, who require additional support in order to participate in the regular education system. In the last thirty years, in Europe and the whole world in general, the number of countries which create education policies and financial resources intended for the children who do not have or access or their access to the regular education curriculum is obstructed from different reasons, is increasing. According to Terzi (2005, p. 444), most commonly these children are: children with SEN, children with learning difficulties and children from vulnerable groups (children in multilingual environments, poor and sick children). Defining the groups of children depends on the used classification and international organizations. It is understandable that the inclusion of all groups of children in ethnically heterogeneous society is a sensitive process that requires time and resources due to the relations between the dominant community and the minorities.

\section{RESEARCH SUBJECT}

The subject of this research are the characteristics of education systems in the European countries and Kosovo, as a condition for better inclusion of children with special needs in regular education systems.

\section{METHODOLOGY}

As a base for the methodology of the research was used analysis of international documents, reviews and evaluations. Analysis of education development processes in the last 20 years, which are fundaments for policy creation and assessment of the situation, represent one of the most important elements of this research. The following methods are used in this research:

- Method of theoretical analysis based on the description of the systems of education;

- Method of comparison;

- Methods of descriptive statistics based on the obtained statistic data represented in frequency (f).

\section{SAMPLE}

The education systems in 12 different countries are included in the research sample:

- 2 countries members of the European Union (Austria and Belgium, Flemish and French region);

- 4 recent members of the European Union (Cyprus, Estonia, Latvia and Slovenia);

- 3 Scandinavian countries (Iceland, Norway and Finland);

- 3 Balkan countries (Macedonia, Montenegro and Kosovo).

The countries included in the research have a population of up to 8 million. The base for the research analysis are the databases of EUROBASE - National system overviews on Education in Europe and on going reforms (www. eurydice.org) and European Agency for people with Special Needs and Inclusioneducation (www.european-agency.org), Eurostat, OECD. The data were obtained through:

- Literature studying;

- Monitoring of statistics and statistical databases. 


\section{RESULTS}

\subsection{Inclusion of children with SEN}

There are various practices in Europe, but in most of the countries exists two track system for the children with special educational needs. That means that the school systems are organized so that the specialized institutions enable the inclusion. Europe increasingly seeks to develop the forms and mechanisms of systems that could include children who cannot participate in the regular education system. Next are shown the main features of all groups of children involved in the research in the countries mentioned in the sample: Austria, Belgium (fl), Belgium (fr), Cyprus, Estonia, Latvia, Finland and Slovenia (as European Union members), Iceland, Norway (a Scandinavian country) and Kosovo, Macedonia and Montenegro (Balkan country).

\subsection{Europe}

Through charts and explanations tables of children with SEN are shown, in EU countries and other European countries and Kosovo.

\subsection{Review of children with SEN}

Table 1 - Education of children with SEN in the examined countries in 2010

\begin{tabular}{|l|l|l|l|l|l|l|l|l|}
\hline \multirow{2}{*}{ Country } & \multicolumn{2}{|c|}{ Inclusion } & \multicolumn{2}{c|}{ Segregation } & \multicolumn{2}{c|}{$\begin{array}{c}\text { Special classes in } \\
\text { ES }\end{array}$} & \multicolumn{2}{c|}{$\begin{array}{c}\text { Total number of } \\
\text { students in } \%\end{array}$} \\
\cline { 2 - 11 } & $\begin{array}{c}\text { Number } \\
\mathrm{f}\end{array}$ & \multicolumn{1}{|c|}{$\%$} & $\begin{array}{c}\text { Number } \\
\mathrm{f}\end{array}$ & $\%$ & $\begin{array}{c}\text { Number } \\
\mathrm{f}\end{array}$ & $\%$ & $\begin{array}{c}\text { Number } \\
\mathrm{f}\end{array}$ & $\%$ \\
\hline AUSTRIA & 15.773 & 2,0 & 11.787 & 1,5 & 965 & 0,12 & 28.525 & 3,6 \\
\hline BELGIUM (Fl) & 8.245 & 1,0 & 46.091 & 5,30 & $\mathrm{~N}$ & $\mathrm{~N}$ & 54.336 & 6,3 \\
\hline BELGIUM (Fr) & 220 & 0,03 & 30.773 & 4,50 & $\mathrm{~N}$ & $\mathrm{~N}$ & 30.993 & 4,5 \\
\hline CYPRUS & 4.860 & 5,83 & 288 & 0,34 & 648 & 0,77 & 5.796 & 6,95 \\
\hline ESTONIA & 5.611 & 5,0 & 3.365 & 3,0 & 1.459 & 1,30 & 10.435 & 9,3 \\
\hline FINLAND & 24.137 & 4,3 & 6.782 & 1,2 & 14.574 & 2,6 & 45.493 & 8,1 \\
\hline ICELAND & 10.159 & 23,34 & 143 & 0,32 & 348 & 0,79 & 10.650 & 24,47 \\
\hline MACEDONIA & $\mathrm{N}$ & $\mathrm{N}$ & 1.322 & 0.65 & $\mathrm{~N}$ & $\mathrm{~N}$ & 1.322 & 0,65 \\
\hline MONTENEGRO & 1.432 & 1,23 & 256 & 0,22 & 86 & 0,07 & 1.774 & 1,52 \\
\hline KOSOVO & 101 & 0,02 & 450 & 0.10 & 523 & 0,12 & 1.074 & 0,24 \\
\hline LATVIA & 2.482 & 1,47 & 6.172 & 3,67 & 1.072 & 0,63 & 9.726 & 5,79 \\
\hline NORWAY & 41.552 & 6,7 & 1.929 & 0,30 & 5.321 & 1,0 & 48.802 & 7,9 \\
\hline SLOVENIA & 7.275 & 4,5 & 2.829 & 1,7 & 400 & 0,24 & 10.504 & 6,5 \\
\hline
\end{tabular}

Resource: European Agency for Development in Special Needs Education, SNE Country data, 2010 November 2012, EURYDICE, 2012

\section{$\mathrm{N}$ is missing}

Table 2 shows the ratio of children set in inclusive forms of education (inclusion), in classes within the special institutions (segregation) and in special classes within regular schools in the countries included in the research for the academic 2010/2011. The results from the table indicate that Norway has the largest number of children in inclusive schools, $6.7 \%$, followed by Estonia, Slovenia, both regions of Belgium and Kosovo. Belgium (Flemish region) has the highest percent of children educated in special institutions (segregation), 5.3\% and $4.5 \%$ in the French region. The lowest percent of segregation appears in Norway by $0.30 \%$ and Finland, $1.20 \%$. Regarding the segregation, Slovenia and Austria are almost at the same level, approximately $1.5 \%$. The numbers about special classes in regular schools point out Finland 
where traditionally exists positive practice in this area, with $2.6 \%$, followed by Estonia with $1.30 \%$ and Norway with $1 \%$. Data on Montenegro show a relatively large number of children in inclusive forms of education, respectively $1.23 \%$, in segregative forms $0.22 \%$ and in special classes $0.07 \%$. The other countries do not have significant deviation regarding the inclusion in special classes. For Cyprus it is characteristic that a large number of students are in inclusive education, almost $6 \%$, while $0.34 \%$ students are segregated, and $0.77 \%$ are in separate classes in regular schools. Iceland has a greater share of students in inclusive education, which is characteristic of all Scandinavian countries. A smaller number of students are in special institutions with $0.32 \%$ and $0.79 \%$ in special classes. If we analyze the total number of children with SEN, we can conclude that it is the highest in Estonia, Finland and Norway, then the Flemish region of Belgium, Slovenia, Austria, the French region of Belgium, Macedonia and Kosovo. The high number of children with SEN in Scandinavian countries indicates that the identification of the children is clearly determined on a level of the local communities. For Macedonia, there is a lack of data on inclusion of children with SEN in regular environments and data for special units, because the methodology for collecting data is not used in other countries of this research.

\subsection{Segregation - Inclusion ratio}

Table 3 - Number of children in inclusion and special institutions in 2010

\begin{tabular}{|l|l|l|l|l|l|}
\hline \multicolumn{1}{|c|}{ Country } & \multicolumn{1}{|c|}{$\begin{array}{l}\text { Generation } \\
\text { of students }\end{array}$} & \multicolumn{1}{|c|}{$\begin{array}{c}\text { Inclusion } \\
\mathrm{f}\end{array}$} & \multicolumn{1}{c|}{$\%$} & \multicolumn{1}{c|}{$\begin{array}{c}\text { Special } \\
\text { institution } \\
\mathrm{f}\end{array}$} & \multicolumn{1}{l|}{} \\
\hline AUSTRIA & 802.519 & 15.773 & 2,0 & 11.787 & 1,5 \\
\hline BELGIUM - Fl. & 871.920 & 8.245 & 1,0 & 46.091 & 5,2 \\
\hline BELGIUM - Fr. & 687.137 & 220 & 0,03 & 30.773 & 4,4 \\
\hline CYPRUS & 83.307 & 4.860 & 5,83 & 288 & 0,34 \\
\hline ESTONIA & 112.738 & 5.611 & 5,0 & 3.365 & 3,0 \\
\hline FINLAND & 559.379 & 24.137 & 4,3 & 6.782 & 1,2 \\
\hline ICELAND & 43.511 & 10.159 & 23,35 & 143 & 0,33 \\
\hline KOSOVO & 301.486 & 101 & 0,03 & 831 & 0,27 \\
\hline LATVIA & 167.760 & 2.482 & 1,47 & 6.172 & 3,67 \\
\hline MACEDONIA & 204.439 & $\mathrm{~N}$ & $\mathrm{~N}$ & 1.322 & 0,65 \\
\hline MONTENEGRO & 117.142 & 1.432 & 1,22 & 256 & 0,22 \\
\hline NORWAY & 615.883 & 41.552 & 6,7 & 1.929 & 0,31 \\
\hline SLOVENIA & 162.902 & 7.275 & 4,5 & 3.229 & 2,0 \\
\hline
\end{tabular}

Resource: SNE DATA, European Agency, 2010

\section{$\mathrm{N}$ is missing}

In order the inclusive process to be assessed, the inclusion-segregation ratio is of great significance. This ratio is related to the definition of SEN used in different countries and the support organization in the local community. Austria adopted the general definition and there are classified only the severe disabilities. The data in Belgium (both regions) show high number of children set in special institutions. In Finland it is recognizable that generally the children are set in inclusive models of education with approximately $4.3 \%$. This fact is due to the highest number of children set in special classes within regular schools and only $1.2 \%$ set in special institutions. In Estonia there is a lower ration between regular and special education. In this country only $5 \%$ of the children are in regular schools and $3 \%$ are enrolled in special schools. For Cyprus it is characteristic that children with special needs are mostly placed in regular schools and only $0.34 \%$ are in special schools. Norway has a long tradition of inclusive 
education system. Only $0.31 \%$ of the children are in special institutions and $6.7 \%$ of them go to regular schools. The same ration in Slovenia is 1:2 in favor of inclusion. In Macedonia, there is a lack of data for children with POP in inclusion due to the non-application of the methodology for data collection, while the percentage of coverage in the special institutions remains constant. Kosovo, although a small number of students, shows a positive result in favor of inclusion. We can conclude that in all countries of this research (for Macedonia there are no data), the inclusive process is developing well. We can conclude that in all of the countries from this research the process of inclusion develops positively except in the both regions of Belgium. For Montenegro, it is characteristic that the greater number of children in inclusion is $1.22 \%$, than the segregated $0.22 \%$. In Latvia it is quite the opposite, $5.67 \%$ of children are segregated and only $1.47 \%$ are involved in an inclusive process. In Iceland, a large number of students are in inclusion - $23.3 \%$.

Table 4: Trend of children with SEN in all segregation forms (special classes and special schools) in the countries of the survey for the period 2004-2010

\begin{tabular}{|l|c|c|c|c|}
\hline \multicolumn{1}{|c|}{ Country } & 2004 & 2006 & 2008 & 2010 \\
\hline AUSTRIA & 1,6 & 1,6 & 1,5 & 1,6 \\
\hline BELGIUM - Fl. & 4,9 & 5,1 & 5,1 & 5,3 \\
\hline BELGIUM - Fr. & 4,2 & 4,3 & 4,4 & 4,5 \\
\hline MONTENEGRO & 0,26 & 0,38 & 0,34 & 0,22 \\
\hline ESTONIA & 4,0 & 4,3 & 4,8 & 4,3 \\
\hline FINLAND & 3,6 & 3,9 & 3,9 & 3,9 \\
\hline ICELAND & $\mathrm{N}$ & 0,33 & 0,36 & 0,33 \\
\hline CYPRUS & 0,26 & 0,62 & 0,89 & 0,55 \\
\hline KOSOVO & $\mathrm{N}$ & 0,21 & 0,20 & 0,22 \\
\hline LATVIA & 4,27 & 3,98 & 4,07 & 4,31 \\
\hline MACEDONIA & 0,65 & 0,58 & 0,58 & 0,65 \\
\hline NORWAY & 0,3 & 0,3 & 0,3 & 1,2 \\
\hline SLOVENIA & 2,0 & 2,0 & 1,9 & 2,0 \\
\hline
\end{tabular}

Source: European Agency, state data

\section{$\mathrm{N}$ is missing}

The table presents the trend of inclusion of children with SEN in specialized institutions for a period of six years. Austria has a constant percentage for the entire period, ie $1.6 \%$. For both parts of Belgium, there is a characteristic slight increase, although the percentage is relatively high, about 5\%. In Estonia and Finland, the percentage of segregated children is around $4 \%$. For Slovenia, the percentage is $2 \%$ for the entire period. The data for Macedonia are from the special schools, which points out that the percentage is low, below $1 \%$, due to the limited capacities for enrolling these children in the institutions. Regarding this parameter, a low percentage is obtained in Kosovo too, that is, under $1 \%$, which can also be related to the capacities for involving these children in the institutions. Data on Montenegro show that the trend of segregation is declining, in Iceland it is relatively constant, and in Cyprus it is growing (from $0.26 \%$ to $0.55 \%$ in 2010 ). 


\subsection{Analysis of the support of children from multilingual backgrounds}

Table 5 - Forms of support of children from multilingual backgrounds in the examined countries.

\begin{tabular}{|l|c|c|c|}
\hline \multicolumn{1}{|c|}{ Country } & $\begin{array}{c}\text { Additional classes } \\
\text { in native language }\end{array}$ & $\begin{array}{c}\text { Coordinator or mediator for } \\
\text { native language support }\end{array}$ & $\begin{array}{c}\text { Instruction in } \\
\text { native } \\
\text { language }\end{array}$ \\
\hline AUSTRIA & $\checkmark$ & $\checkmark$ & \\
\hline BELGIUM (fl.) & $\checkmark$ & $\checkmark$ & \\
\hline BELGIUM (fr.) & $\checkmark$ & $\checkmark$ & $\checkmark$ \\
\hline CYPRUS & & $\checkmark$ & $\checkmark$ \\
\hline ESTONIA & $\checkmark$ & $\checkmark$ & \\
\hline FINLAND & $\checkmark$ & $\checkmark$ & $\checkmark$ \\
\hline ICELAND & $\checkmark$ & $\checkmark$ & $\checkmark$ \\
\hline KOSOVO & & & $\checkmark$ \\
\hline LATVIA & & $\checkmark$ & $\checkmark$ \\
\hline MACEDONIA & $\checkmark$ & & \\
\hline MONTENEGRO & $\checkmark$ & & \\
\hline NORWAY & & & \\
\hline SLOVENIA & & & \\
\hline
\end{tabular}

From the table above, it can be concluded that all countries involved in the research organize additional classes for children from multilingual backgrounds, except the new members of the European Union and the Balkan countries. In these countries there are also school coordinators, and four countries organize minority language instruction (the first language of the child in the family). Montenegro, Kosovo and Macedonia provide native language instruction, while Iceland and Cyprus provide extra hours and coordinators. In Latvia the practice is to have a coordinator for native language support.

\subsection{Analysis of the legislative framework}

Table 6 - Children with SEN legislation in the examined countries

\begin{tabular}{|l|c|c|c|}
\hline \multicolumn{1}{|c|}{ Country } & Status & General legislation & Special legislation \\
\hline AUSTRIA & EU & $\checkmark$ & $\checkmark$ \\
\hline BELGIUM & EU & $\checkmark$ & $\checkmark$ \\
\hline CYPRUS & EU & & $\checkmark$ \\
\hline ESTONIA & NEU & $\checkmark$ & \\
\hline FINLAND & SC & $\checkmark$ & \\
\hline ICELAND & SK & $\checkmark$ & \\
\hline KOSOVO & BA & $\checkmark$ & $\checkmark$ \\
\hline LATVIA & EU & $\checkmark$ & $\checkmark$ \\
\hline MACEDONIA & BA & & $\checkmark$ \\
\hline MONTENEGRO & BA & & \\
\hline NORWAY & SC & $\checkmark$ & \\
\hline SLOVENIA & NEU & $\checkmark$ & \\
\hline
\end{tabular}


The table shows the way countries approach the inclusion of children with SEN in the legislative framework. The countries which have general education legislation approach have more developed inclusive schools. Such countries are Finland, Iceland, Latvia, Norway and Kosovo. Some of the countries decided to regulate the SNE by both general and special legislation (Austria, Belgium, Estonia and Slovenia). Countries of Cyprus, Montenegro and Macedonia have regulated it through a special area for special educational needs.

LEGEND:

EU - European Union member country

SC - Scandinavian country

NEU - Recent (new) European Union member country

BA - Balkan country

\section{DISCUSSION AND INTERPRETATION OF THE DATA}

\section{Analysis of inclusion-segregation ratio}

The data regarding the education of students with SEN in Europe indicate that only $2 \%$ of SEN students are educated in segregated environments. It is difficult to assess the extent to which a progress has been made considering the number of segregated students and inclusive provisions in European countries. However, over the last few years, countries with relatively greater special needs in the education system, in separate cases, showed a continuous increase in the number of students in segregated environments, which now implement inclusive policies. In order to understand the inclusive processes as a whole, in some countries it is necessary to apply the processes of inclusion and segregation. Table 17 displays that Belgium has a high percent of children with SEN in special schools. In Estonia, 5\% of the children are in regular schools and 3\% in special schools. This result can be changed in the further period, taking into account that since 2008, there are reforms and changes in progress. Finland characterizes with the fact there are many children in inclusive forms of education, around $4.3 \%$. This percent mainly refers to children from separate classes in regular schools, and only $1.2 \%$ are in special schools. In Norway, the total number of children with SEN rose from 5.7\% in 2004 to $7.9 \%$ in 2010. Slovenia is specific because the percent of children in special school remains constant for years $(2 \%)$, but the number of included children is increasing. As far as Iceland is concerned, a large number of students are already in inclusion, while the percentage of children in segregation is below $1 \%$. Cyprus is a country known to positively receive children.. That's what the results show. In general, all students with special needs are in regular schools and only $0.34 \%$ are in special schools.

The data about Kosovo indicate that the children with SEN are not properly identified. Because the legislative framework in Kosovo is in use, the reason about that could be the badly developed network of the Commission for identification of the children. Norway has a long tradition of inclusive education system. Only $0.31 \%$ of the children are in special institutions and $6.7 \%$ go to regular schools. When we analyze the data from the countries in this research, we can conclude that some are more oriented toward inclusion than others. Also, some of the countries are differently oriented in the implementation process or are currently in a process of education reforms. The data showed strong segregation trend in Belgium, Estonia and Latvia. Data on Macedonia can not be statistically commented on, because we have received data for segregation alone, which amounts to $0.65 \%$. In this research, most oriented countries towards inclusion are Austria, Cyprus, Finland, Iceland, Montenegro, Slovenia, Macedonia, Norway and Kosovo. The statistical significance of the obtained data in individual countries have to be taken into consideration, regarding the previous statement, especially the data from Kosovo. 
Macedonia and Montenegro. In this context, there is a dilemma about the monitoring, diagnostics and operation of the Committee for the evaluation of children with disabilities.

\section{Analysis of the support of children from multilingual backgrounds}

The cross analysis of the researched countries has shown great diversity in the practice of helping children from multilingual environments. The best practice is evident in the Scandinavian countries, where there exists very long tradition of migration and attitude towards diversity regarding human rights of every individual. In these countries it is important for the child to be included in kindergarten with one of the parents, most often the mother, regardless of whether the parents are already working and learning the language of the majority. The goal of this practice is the bilingual approach, which should start as soon as possible, but certainly soon after the child has moved to the country. Based on the overview from Table 20, the differences in providing assistance to children from multilingual environments in the form of additional classes can be seen, in the form of additional classes, learning the language of instruction in the pre-school period and the presence of coordinators in primary schools for children from multilingual environments.

\section{Analysis of the legislative framework}

One of the main aspects is how the countries approach the inclusion of children with SEN in the legislative framework. Mostly the approach is related to the definition of the groups of children. Countries that have more general definitions tend to determine the rights of these children in the general legislative framework that regulates the education of all children. Thus on a declarative level, they are moving closer to the inclusive education and the concept "Schools for All" mentioned in the Salamanca Statement. In table 16 can be seen that most of the countries included in the research have combined legislative framework, which includes a mix of general and special education laws. Such countries are Austria, Belgium, Estonia, Latvia and Slovenia. Only Finland, Norway, Iceland, Cyprus and Kosovo regulate the education in the general legislative framework. Special laws have Montenegro and Macedonia.From the above it can be concluded that the countries which have a basis for such a legislative framework are the countries that have a good general economic situation, tradition of inclusion of vulnerable children and have adopted general definitions of children with SEN (except Kosovo).

\section{Overall assessment based on the data collected for individual countries}

The data for the analysis in this paper show that EU Member States have no difficulty in collecting data, ie in the data collection are included other European institutions as well as non-EU countries. The collection of data at European level for the Member States are carried out according to the same methodology and the same standards at regular intervals.

\section{CONCLUSION}

One of the biggest challenges in the last twenty years, given the growing number of children with SEN in regular schools is how to provide necessary support on a local level and how to be established services of support. According to Muijsu (2011), the education system is under pressure to make a change that would allow inclusion of all children. Through our analysis, we tried to identify the various supports the children from different groups receive in the education system: children with SEN. We took into account that the countries, as well as the education systems, differ in terms of tradition of inclusive education, attitude towards human rights and financial opportunities (Mitchell, 2008). The countries relevant for this research have a population of up to 8 million: Austria, Belgium (old EU members), Estonia, Slovenia (new EU members), Finland and Norway (Scandinavian countries) and (Balkan country) Kosovo, Macedonia and Montenegro. This criterion was taken into account because 
of the reliable comparisons of education systems. Data collection for this area is a task that requires time. That is due to the existence of non-standard statistical bases, different definitions of children with SEN and the procedures for their identification on the one hand and the sensitivity of the identities of the children and their families on the other. The collection of other data used in the research is obtained from the statistical bases of the European Agency for the education of persons with disabilities and inclusive education, bases OECD and EURYDICE and statistical databases of the Ministry of Education in Kosovo, Macedonia and Montenegro. The data are presented in tables and are expressed in structural percent. For the statistical analysis in the empirical part, the following statistical methods were used: frequency (f); structural percent (\%). Considering that this is a case study, there is a greater risk with the statistical results. The practical value of this research is the development of foundation for practical proposals regarding the establishment of the legislative framework. The overall analysis showed that there is a positive orientation towards inclusive processes in all countries, including Kosovo, Macedonia and Montenegro. Due to the economic situation and increasing population migration, the inclusion process happens at a slower rate. All education reforms in the countries of Europe have occurred because of the increased number of children with SEN. Because of this phenomenon there is a need of creating a new ways of conducting researches of the students that are going to be good for all children (students). One important thing for the initial comparison of the status of children with SEN in separate countries is the basic definition. From this can be concluded the direction in which the inclusive education goes and the attitude of the social environment towards diversity. Environments that have a long historical tradition in the field of inclusion often have a favorable economic situation. Examples for such countries are Austria, Belgium, Norway and Finland. Estonia is also moving towards that direction. In the basic definition, in Kosovo, Macedonia, Montenegro and Slovenia are stated 8-9 groups of children with SEN. Slovenia has a well-established system for identifying children with SEN and provides enough support in the classroom and outside of it. 


\section{REFERENCES}

BAJRAMI, V. (2018). Education for students with special educational needs in Europe and Balkan. Research in education and rehabilitation, 66. Tuzla, B\&H

BAJRAMI, V.and AJDINOSKI G. (2018). Analysis of political and legal framework of inclusive education in multicultural environments some countries Eu and the Balkans. In Book of peaper: Skopje: Faculty of philosophy

BAJRAMI, V. (2018). Inclusive education policies in some EU countries and the Balkans. International Scientific Conference Seventeenth International Scientific Conference The teacher of the future knowledge - international journal scientific papers vol 23.1, Promoted in Budva, Montenegro.

BAJRAMI, V. (2017). Inclusive education system in Europe and in Kosovo. Mesleki Bilimler Dergisi (MBD), 6(2), 134-142.

BAJRAMI, V. (2017). Approaches of education of children with special needs children and multilingual children in multicultural environments, Twelfth International Scientific Conference KNOWLEDGE WITHOUT BORDERS, Vrnjacka Banja, Serbia

BAJRAMI, V. (2016). Policy and practice for inclusive education in Europe and the Kosovo, Eleventh International Scientific Conference KNOWLEDGE IN PRACTICE Bansko, Bulgaria.

BAJRAMI, V. and GLOBACNIK, B. (2012): Evaluation and recognition of children with special educational needs.In Book of peaper: Skopje: Faculty of philosophy

BAJRAMI, V. and GLOBACNIK, B.(2011): Current models and approaches with children with special educational needs Educologia the University of Pristine, Faculty of Education Pristine 5/2011. Prishtine: 266-277.

BAJRAMI, V. (2011): Towards inclusive education in Kosovo-possibilities and limitations, Educologia Proceedings of the symposium with international participation in the interdisciplinary aspects of education, the University of Pristine, Faculty of Education 4 / 2010. Pristine: 245-255.

DIXON, S. (2005). Inclusion - Not segregation or integration is where a student with special needs belongs. Journal of Educational Thought, 39(1), 33-53.

European Agency for Development in Special Needs Education, (2012). Special Needs Education Country Data 2012, Odense, Denmark: European Agency for Development in Special Needs Education.

European Agency for Development in Special Needs Education (2012). TEACHER EDUCATION FOR INCLUSION-Profile of Inclusive Teachers. Odense, Denmark: European Agency for Development in Special Needs Education.

European Agency for Development in Special Needs Education, (2011). Teacher Education for Inclusion Across Europe - Challenges and Opportunities, Odense, Denmark: European Agency for Development in Special Needs Education.

European Commission, DG Education and Culture (2011). Thematic Working Group 'Teacher Professional Development': Report of Peer Learning Activity: Policy Approaches to Defining and Describing Teacher Competences Organisation for Economic Cooperation and Development (2005) Teachers Matter: Attracting, Developing and Retaining Effective Teachers. Paris: OECD 
EUROSTAT, (2012). The statistical office of the European Union Eurostat and are based on data from the EU-SILC survey, had a reorganisation on 1 January 2012. Europe in figures - Eurostat yearbook 2012 presents a comprehensive selection of statistical data on Europe.

GLOBAČNIK, B. and BAJRAMI, V. (2012): Inclusion of S.E.N Children in Education, II-nd Internacional Scientific Conference'Dynamics of European Integration through Social Inclusion" Tirana

GLOBAČNIK, B. and BAJRAMI, V. (2012): Views on education in multicultural environment - Prishtina

GLOBAČNIK, B. and BAJRAMI, V. (2011): Early childhood intervention - The situation in Europe 2005-2010. In: Book of paper: Symposium Early Intervention and developmental disorder with international participation. Skopje: Faculty of philosophy, 555-576.

MEIJER, C.J.W. (2010). Special Needs Education in Europe: Inclusive Policies and Practices. Middelfart: European Agency for Development in Special Needs Education.

MEIJER, C. (2003). Inclusive Education and Classroom Practices. Middelfart: European Agency for Development in Special Needs Education.

MITCHELL, D. (2008). What really works in special and inclusive education. Using evidence - based teaching strategies. London: Routledge.

MITCHELL, D. and DESAI I. (2005). Diverse cultural contexts for inclusive education in Asia. In D. Mitchell (ed.), Contextualizing inclusive education: Evaluating old and new international perspectives (pp. 166-201). London: Routledge.

OECD, (2007). Students with Disabilities, learning, difficulties and disadvantages: policies, statistics and indicators. Paris: OECD.

OECD, (2009). Students with Disabilities, learning, difficulties and disadvantages in the Baltic Staes, South Eastern Europe and Malta, education policies and indicators. Paris: OECD.

OECD, (2010). Sickness, disability and work: breaking the barriers. A 2010. synthesis of findings across OECD countries. Paris: OECD.

TERZI, L. (2005). Beyond the Dilemma of Difference: The capability Approach to Disability and Special Educational Needs. Journal of Philosophy of Education,pp. 443-458.

UNESCO, (2007). Convention on the Protection and Promotion of the Diversity of Cultural Expressions: Possible Statistical Implications? This paper is an expert discussion paper on the possible statistical implications of the UNESCO Convention on the Protection and Promotion of the Diversity of Cultural Expression.

UNESCO-IBE, (2008). Conclusions and recommendations of the 48th session of the International Conference on Education (ED/BIE/CONFINTED 48/5) [online] Available at: <http://www.ibe.unesco.org/en/ice/48th-ice-2008/conclusions-andrecommendations. html $>$ [Accessed 13.06.2012]

UNESCO, (2009). Policy Guidelines on Inclusion in Education. [online] Available at: $<$ http://unesdoc.unesco.org/Ulis/cgibin/ulis.pl?catno=177849\&set=4A9F89E7_2_250 $\& \mathrm{gp}=1 \& 11=1>$ [Accessed 21.01.2013] 
UNICEF, (2013). UNICEF Report on the State of the World's Children 2013 The Rights of Children with Disabilities.

UNITED NATIONS, (2006). Convention on the Rights of Persons with Disabilities. New York: United Nations. 